\title{
Mangrove composition and structure at the Welu Estuary,Khlung District, Chanthaburi Province, Thailand
}

\author{
Suk-ueng, N. ${ }^{1}$, Buranapratheprat, A. ${ }^{2}$, Gunbua, V. ${ }^{2}$, Leadprathom, N. ${ }^{3}$ \\ ${ }^{1}$ Biological Science Program, Faculty of Science, Burapha University, Chonburi 20131, Thailand \\ ${ }^{2}$ Department of Aquatic Science, Faculty of Science, Burapha University, Chonburi 20131, Thailand \\ ${ }^{3}$ Faculty of Marine Technology, Burapha University, Chanthaburi 22170, Thailand.
}

\begin{abstract}
The largest mangrove areas in the eastern part of Thailand are located in Chanthaburi province, but most of them have deteriorated and are abandoned. A healthy mangrove area in the Weluestuary, Khlung district, Chanthaburi province is selected as the study area. Mangrove composition, structure and distribution were investigated to be used as a baseline for mangrove conservation in the surrounding area. Twenty-six mangrove speciesincluding 15important true mangrove species, namely A. alba, A. officinalis, B. cylindrica, $B$. gymnorrhiza, B. hainesii, B. parviflora, B. sexangula, C. tagal, E. agallocha, R. apiculata, R. mucronata, S. caseolaris, S. ovata, X. granatum and X. moluccensis, were identifiedfrom the field survey.Based on structure and community, R.apiculata appeared dominant in the area. The composition and structure results, in terms of number of trees, total stem basal area, tree density and IVI, revealed distribution of these true mangroves following different distances. Consequently, E. agallocha, X. granatum and X. moluccensis presented in the same zones as theAvicenniaceae, Rhizophoraceae and Sonneratiaceae families. This result suggested that E. agallocha, X. granatum and X. moluccensis can be used to rehabilitate the lost mangroves in the Welu estuary and other deteriorated and abandoned mangrove areas.
\end{abstract}

Keywords: Mangrove species, Mangrove structure, Mangrove community, Mangrove conservation, Chanthaburi province

\section{Introduction}

Mangrove, an estuarine ecosystem, is located in the sheltered coastline and inland areas along the banks of rivers and streams in the tropics and subtropics of the world. The benefits of mangrove structuresincludeproviding a nursery habitat for young aquatic animals, coastal fisheries, sediment trapping and coastal protection from storms and waves.Structural and community characteristics of mangrove forestsare reflected by thedistribution of mangrove species[1]. According to Tomlinson[2], 114 mangrove species were found throughout the world.Among them, 50 species were found in Southeast Asia[3]. Three pioneer families, namely Avicenniaceae, Rhizophoraceae and Sonneratiaceaeare important to mangrove ecosystems due totheir structural characteristics. Natural adaption of individual mangrove species has resulted in mangrove structure and zonation $[4,5]$.

Over-exploitation of mangrove for such activities as, aquacultures and tourism are considered as major causes to mangrove area decreases [6, 7]. Global mangrove areas have reduced during the past 25 years $(1980-$ 2005) from 18.8 to 3.6 million hectares (ha). Mangrove areas in Thailand decreased from 368,000 ha in 1961 [8] to 276,000 ha in 2010 [9].Such a situation requires efficient rehabilitation supported by research and knowledge to maintain complex mangrove ecosystems[10].

The Welu estuarine mangrove is considered as the largest mangrove area in the eastern part of Thailand with high abundance and biodiversity of flora and fauna [11]. Unfortunately, this area decreasedin size from 19,000 ha in 1975 [11]to 7,206 ha in 2009 [12]due to shrimp farming and tourism. Demand forthe mangrove reforestation is therefore needed. This researchaims to investigatemangrove composition and structurein a healthy mangrove area in the Welu estuary, Khlung district, Chanthaburi province. The survey results will provide knowledge and support for mangrove ecosystem studies and conservation.

\section{Materials And Methods}

The mangrove area in the Welu estuary, under responsibility of Mangrove Resource Development Station 2 (MS2), Khlung district, Chanthaburi province, is chosen as the study site (Fig. 1). The approximate area is 134 ha located from latitude $12^{\circ} 21^{\prime} 42^{\prime \prime} \mathrm{N}$ to $12^{\circ} 23^{\prime} 20^{\prime \prime} \mathrm{N}$ andlongitude $102^{\circ} 19^{\prime} 59^{\prime \prime} \mathrm{E}$ to $102^{\circ} 21^{\prime} 38^{\prime \prime} \mathrm{E}$.

Visual surveys on foot and by boat were carried out from December 2009 to February 2010. A healthy mangrove area was selected from the topographic map, with a scale of 1:50000, Series L 7018 Sheet 5334I [13], the satellite image retrieved from the Geo-Informatics and Space Technology Development Agency (GISTDA) andthe survey results of the study site. Line transects $[14,15]$ were applied on the study site for ground truth observations. Theywere used for collecting the information of mangrove species following Sutherland[14] and 
Krebs[16]. The length of transects variedfrom $150 \mathrm{~m}$ to $825 \mathrm{~m}$ in accordance with size and shape of the study area (Fig. 1). The dimension of each plot was $15 \times 15 \mathrm{~m}[17]$, and the numbers of plot were calculated from this [18]. Seventy-six study plotswere fixed along the transect lines,anda stratified random sampling technique with mangrove zonation derived from field survey results was used.

All live mangrove trees with diameter at breast height (DBH) (1.30 m from the ground) greater than4 $\mathrm{cm}$ [11] in the study plots were measured from January to March 2011. The number of individual tree and tree species [2]in each plot were recorded. For small trees, DBH was directly measured using a Vernier caliper, but for large trees, tree girth at breast height $(\mathrm{GBH})$ was measured using a measuring tape. GBH was then converted to DBH by divided by $\pi[17,19]$.

Structural analysis was determined using the density of each species (number of tree $0.01 \mathrm{ha}^{-1}$ ), species basal area $\left(\mathrm{m}^{2} 0.01 \mathrm{ha}^{-1}\right)$ and total basal area of all species $\left(\mathrm{m}^{2} \mathrm{ha}^{-1}\right)[20]$. The importance value index (IVI) was used as an indicator of a given species within a stand of mixed mangrove species [21]. It was calcualted by summation of three terms namely the relative density, relative dominance and relative frequency of each species. Community analysis was defined by using Shanon-Wiener Diversity Index [22]. Overall analytical process is shown in Figure 2.

\subsection{Mangrove species composition and structure}

\section{Results}

Ten line transects (298 plots)were established, and the studyarea was separated into 2 zones (zone A and B). Zone A included 4 line transects (A1 A2 A3 and A4), and Zone B had 6 line transects (B1 B2 B3 B4 B5 and B6). Each line transect of Zone A and Zone B was randomly sampled for 4 and 10 plots, respectively. The number of selected plots altogether totalled 76(Fig. 1).Twenty-six species of mangroves were found in this study site.Of these 15 species, namelyAvicennia alba, Avicenniaofficinalis, Bruguieracylindrica, Bruguieragymnorrhiza, Bruguierahainesii, Bruguieraparviflora, Bruguierasexangula, Ceriopstagal, Excoecariaagallocha, Rhizophoraapiculata,Rhizophoramucronata, Sonneratiacaseolaris, Sonneratiaovata, Xylocarpusgranatum and Xylocarpusmoluccensisweredefined as important true mangrove species.In total 2,748 trees were sampled, of which 2,143 trees (78\% of all number of trees) in 74 plots of occurrence were identified as $R$. apiculata.Species diversity of the MS2 site was 1.06 . $R$. apiculata showed the highest species diversity at 0.194,followed byE.agallocha (0.144), Lumnitzeraracemosa(0.120) and Lumnitzeralittorea (0.116) (Table 1).

Mean DBH ofimportant true mangrove species with a large number of trees in medium size classes was compared to number of treesin small and large stem classes (Fig. 3). For instance, A. alba and A. officinalis appear in mean DBH ranged from 9.6-24.2 cm. X.granatumand X.moluccensis show mean DBH in the range of 9.1-15 cm. Species basal area and tree density of each mangrove speciesis as shown in Table 1 . X.moluccensisshowed maximum basal area $\left(62.05 \mathrm{~m}^{2} 0.01 \mathrm{ha}^{-1}\right)$, followed byX.granatum $\left(36.81 \mathrm{~m}^{2} 0.01 \mathrm{ha}^{-1}\right)$, Heritieralittoralis $\left(36.17 \mathrm{~m}^{2} 0.01 \mathrm{ha}^{-1}\right)$, R.apiculata $\left(28.2 \mathrm{~m}^{2} 0.01 \mathrm{ha}^{-1}\right)$ and E.agallocha $\left(21.09 \mathrm{~m}^{2} 0.01 \mathrm{ha}^{-1}\right)$.The basal area of all species in the study site was $2.63 \mathrm{~m}^{2} \mathrm{ha}^{-1}$. Tree density for individual species varied from 0.26 to 1,599 trees $0.01 \mathrm{ha}^{-1}$. R. apiculatamet with maximum tree density $\left(1,599\right.$ trees $\left.0.01 \mathrm{ha}^{-1}\right)$ or $78 \%$ of the total tree density. This is followed byE.agallocha $\left(96.3\right.$ trees $\left.0.01 \mathrm{ha}^{-1}\right)$, L.racemosa $\left(73.9\right.$ trees $\left.0.01 \mathrm{ha}^{-1}\right)$, L.littorea $(70.9$ trees $0.01 \mathrm{ha}^{-1}$ ) and B.gymnorrhiza (47.8 trees $0.01 \mathrm{ha}^{-1}$ ), respectively (Table 1). As shown in Table 2, the greatest number of IVI was recorded for R. apiculata(120.48), followed by X.moluccensis (26.08), E.agallocha (24.80) and X.granatum(22.27).

\subsection{Mangrove distribution and zonation}

The results from structural analysis described in section 3.1 can be categorized by distribution of mangrove species in 9 zones according to landward distances from the Welu river for the 0 to $>720 \mathrm{~m}$ (Table 3). The results of this relationship are shown in Figures 4-6. Twelve species of important true mangroves, namely A.alba, A.officinalis, B.gymnorrhiza, B.parviflora, B.sexangula, C.tagal, E.agallocha, R.apiculata, R.mucronata, S.caseolaris, X.granatum and X.moluccensis are mostly found in zone $1(0-90 \mathrm{~m})$.

High total stem basal areaof about 83.1, 48.4, 19.5 and $19.2\left(\mathrm{~m}^{2}\right)$ for X.moluccensis, X.granatum, E.agallocha and R.apiculata, respectively (Fig. 4) are dominant in zone 1. The tree density in zone 1 (664.9 trees $0.01 \mathrm{ha}^{-1}$ ) is also higher than in other zones. The numbers of speciesand treesdecreasefrom zone 2 to zone 9. Total stem basal area and tendency of tree density $\left(\mathrm{R}^{2}=0.8043\right)$ also decrease with increasing landward distances from the Welu river (Fig. 5).

The highestIVI of important mangrove species are mostly found from zone 1 to zone 3.IVIof E.agallocha, X.granatum and X.moluccensis are, for example, 124.5, 51.63 and 46.92, respectively. However, 6 important mangrove species, B. cylindrica, B. parviflora, B. sexangula, C. tagal, E. agallocha, R. apiculata and $S$. ovata, showed higher IVI in zone 4to zone 9 than that zone. B. hainesii, B.sexangulaand C.tagalshowed high IVI in zone 5 (22.02), zone 6(33.61) and zone 4 (18.22), respectively. B. parviflora and $S$. ovatapresented the 
highest IVI in inland area (zone 8), while $R$. apiculatashowed high IVI inzone 4 to zone 9 (except zone 8) (Fig. $6)$.

\section{Discussion}

According to the regional mangrove classification scheme, this mangrove area is described as riverine forest,found in river banks and creeks that receive a high freshwater input from upstream and are flooded daily by the tidal regimes [1,23].The number of mangrove species at the present time is more than thatrecorded byAksornkoae [11].Four species namely Acrostichumaureum, $R$. candelaria ( $R$. apiculata), $R$. mucronata and Lumnitzera spp.were investigated. Eighteen species in 7 families defined as true mangroves, growing in the zone of tidal influence [24] are higher than that in the Coringa mangrove forest, the Godavari Delta, India. They also confirm the high biodiversity of the mangrove forest (following the discussion of Ashton and Macintosh [25]) in MS2 site. Among them, 15 species are considered as important true mangroves because their structural characteristics (e.g. root systems) are beneficial to a mangrove ecosystem [23].Obviously, R.apiculatais dominant because of a high number and frequency (number of plots of occurrence) distributed in the area. Other species with low frequencies are restricted to specificareas of the forest [26]. The mangrove forest has higher species diversity than tree communities in the mangrove reserve area on Qi'ao Island in the Pearl river estuary, China [27]. On the other hand, species diversity is lower than in Sematan study plots, Malaysia [25] and Sundarban mangrove forest, Bangladesh [28].

Mean DBH of important true mangrove species in Figure 3 is more abundant in the medium size class $(5-15 \mathrm{~cm})$ compared to those with small $(<5 \mathrm{~cm})$ and large $(>15 \mathrm{~cm})$ stems [29]. The results of DBH classification show that structure of mangrove species has been developing. Growth of the tree diameterin the area is expected to increase year by year (e.g. Chen et al. [30]). Species basal area of $R$. apiculata occupies less of the mangrove area than $X$. granatum and $X$. moluccensisbecause DBH of $R$. apiculata in natural forest was frequently observed as $10 \mathrm{~cm}$ in diameter [29]. Consequently, $X$. granatum and $X$. moluccensiswere the most important species, based on $\mathrm{DBH}$ and species basal area due toa $38 \%$ contribution to total species basal area. However, they showed lower tree density thanR. apiculata, E. agallochaand B. gymnorrhiza, respectively(Table 1). The MS2 mangrove area also has a wide range of species basal area and tree density following different distance of plots. This indicates that the mangrove ecosystem in this area has a variety of structure and composition $[25,31]$. Based on these results, this mangrove area can be determined as a healthy mangrove ecosystem.

Mangrove conservation should considermangrove composition and structure according to their zonation [32, 33]. Nine categories of distances were established to represent species compositions and structures. The quantitative values especially in tree density decrease logarithmically as the distance increasesfrom river to land. The highest number of important true mangroves (12 species), with the greatest structural development are found in zone 1 adjacent to the Welu river. The results suggested that not only the main pioneer families (Avicenniaceae, Rhizophoraceae and Sonneratiaceae) but also Euphorbiaceae (E.agallocha) and Meliaceae(X.granatumand X.moluccensis) are vital to this ecosystem.Although, E. agallocha seemed to prefer land area (zone 2, 3 and 6), the species exhibited a high total stem basal area $\left(19.5 \mathrm{~m}^{2}\right)$ and number of trees ( 55 trees) in zone 1.

Zonation of E. agallocha in the Coringamangrove forest is mostly found in land area [34, 35]. In addition, Ashton and Macintosh [25] observed that $X$. granatumin Sematan mangrove forest in Malaysiawas found in middle and high tide zones.X. granatum and $X$. moluccensiswere presented in the same zone in the mangrove area of western peninsular Malaysia [36, 37]. X. moluccensisin the SegaraAnakan mangroves in Indonesia showed the zonation in high tide and were occasionally inundated by exceptional tide [38, 39]. Surprisingly, E.agallocha, X.granatumand X.moluccensisin MS2 mangrove forest can naturally adaptto the same environmental factors as pioneer species. They are, therefore, able to be replanted in the lost mangrove forests. In most mangrove areas, such as in China, Colombia, Indonesia and Panama, three main pioneer families were planted for mangrove rehabilitation [41]. In Thailand, reforestation of abandoned shrimp ponds used only Rhizophora family includingB. cylindrica, B. parviflora, C. tagal, R. apiculata and R. mucronata (e.g. Iftekhar [42]).However, suitable species for plantingin a specific mangrove area should be decided by environmental conditions according to mangrove zonation so that reforestation and rehabilitation in a deteriorated mangrove area will be successfully achieved [43, 44, 45].

\section{Conclusion}

The mangrove area in the Welu estuary, Khlung district, Chanthaburi province, is considered as a healthy mangrove ecosystem. Twenty-six mangrove species were identified in the field survey. Of these 26 species, 15 species, namely A.alba, A.officinalis, B.cylindrica, B. gymnorrhiza, B. hainesii, B. parviflora, B.sexangula, C.tagal, E. agallocha, R. apiculata, R. mucronata, S. caseolaris, S. ovata, X. granatum and X. moluccensis were defined as important true mangrove species. Rhizophoraapiculata is dominant in the area 
because it showed the highest number and frequencyof treesin the study site. The composition and structure resultsalso revealed the distribution of these mangroves by distances from the river.E. agallocha, X. granatum and $X$. moluccensis presented the same zonation asAvicenniaceae, Rhizophoraceae and Sonneratiaceae families. This result suggests that $E$. agallocha, $X$. granatum and $X$. moluccensiscan be used to rehabilitatethe lost mangroves in the Welu estuary and other deteriorated and abandoned mangrove areas.

\section{Acknowledgements}

We are grateful to thank Faculty of science, Burapha University for supporting the research fund. We would like to express our thanks to the Geo-Informatics and Space Technology Development Agency (GISTDA) for their kind support in providing satellite images. We would like express our deep thanks to the staffs of the Mangrove Resource Development Station 2, Khlung district, Chanthaburi province, Thailand for their kindness in supplying rooms and assistance with the field survey.We are very grateful to Assist. Prof. SomsookMatchacheep, Dr. KarnjanaHrimpaeng, lecturers in the Faculty ofScience, Burapha University and Mr. KomronLeadprathom, head of community forest development project. Our thanks are also presented tostudents of Department of Aquatic Scienceand Faculty of Marine Technology, Burapha Universityfor mangrove field survey and data collection. We would like to express our thanks to Assist. Prof. Dr. ArnonChaisuriya, Language Institute, BuraphaUniversity for proofreading the manuscript.

\section{References}

[1] A.E. Lugo, and S.C. Snedaker, The ecology of mangroves, Annual Review of Ecology and Systematics, 5, 1974, 39-65.

[2] P.B. Tomlinson, The botany of mangroves (United Kingdom: Cambridge University Press, 1986).

[3] FAO, The world's mangroves 1980-2005 (Italy: Food and Agriculture Organization of The United Nations, 2007).

[4] S. Aksornkoae, Ecology and biology of mangroves, Proc. of the ECOTONE IV: Ecology and Management of Mangrove Restoration and Regeneration in East and Southeast Asia, SuratThani, Thailand, 1995, 20-36.

[5] J.P. Walsh, and C.A. Nittrouer, Mangrove-bank sedimentation in a mesotidal environment with large sediment supply, gulfof Papua, Marine Geology, 208, 2004, 225-248.

[6] S. Aksornkoae,Present status of the global mangrove ecosystem, in A. Miyawaki (Ed.), Ecological studies on thevegetation of mangrove forests in Thailand (Yokohama: Yokohama National University, 1985),115-124

[7] J.M.Kovacs, J. Wang, and F. Flores-Verdugo, Mapping mangrove leaf area index at the species level using IKONOS and LAI-2000 sensors for the Agua Brava Lagoon, Mexican Pacific,Estuarine, Coastal and Shelf Science, 62, 2005, 377-384.

[8] V. Jintana, Rehabilitation of mangrove ecosystem in Thailand, Thai Journal of Forestry, 15(1), 1996, 73-79.

[9] FAO,Global forest resources assessment 2010 country report, Thailand (Italy: Food and Agriculture Organization of The United Nations, 2010).

[10] B.B.Walters, P.Rönnbäck, J.M.Kovacs, B.Crona, S.A.Hussain, R.Badola, J.H.Primavera,E. Barbier, andF. Dahdouh-Guebas, Ethnobiology, socio-economics and management of mangrove forest: A review,Aquatic Botany,2008, 1-17.

[11] S. Aksornkoae, Structure, regeneration, and productivity of mangroves in Thailand. doctoral diss., Department of Botany and Plant Pathology, Michigan State, 1975.

[12] P. Mansilp, Evaluation of procedure on objective plans, Division of mangrove administrative 1 Year 2011 (Chonburi: Division of Mangrove Administrative 1, 2011).

[13] Royal Thai Survey Department, Topographic map (1:50,000 scale) of AmphoeKhaoSaming series L7018 sheet 5433 I (Bangkok, Thailand: Royal Thai Survey Department, The Supreme Command Headquarters, 2002).

[14] W.J. Sutherland, Ecological census techniques (New York: Cambridge University Press, 1996).

[15] G.M.Wagner,Y.D. Mgaya, F.D.Akwilapo, R.G.Ngowo, B.C.Sekadende, A.Allen, N.Price,E.A. Zollet, and N. Mackentley,Restoration of coral reef and mangrove ecosystems at Kunduchi and Mbweni, Dar es Salaam, with community participation, Proc. 20th Anniversary Conf. on Advances in Marine Sciences in Tanzania, Zanzibar, Tanzania,2001, $467-488$.

[16] C.J. Krebs, Ecological methodology (2nded.) (California: Addison Wesley Longman, 1999).

[17] S.English,C. Wilkinson, and V. Basker,Survey manual for tropical marine resources(Townsville: Australian Institute of Marine Science, 1994).

[18] J.R. Jensen, Introductory digital image processing: A remote sensing perspective (2nded.)(United States of America: Pearson Prentice Hall, 1996).

[19] P.W. West, Tree and Forest Measurement (2nd ed.) (Germany: Springer, 2009).

[20] T.Balasubramanian,K. Kathiresan, and S.A. Khan, International training course on mangroves and biodiversity (Tamil Nadu: Centre of Advanced Study in Marine Biology, Annamalai University, 2001).

[21] D.J. Pool, S.C. Snedaker, and A.E. Lugo, Structure of mangrove forests in Florida, Puerto Rico, México, and Costa Rica, Biotropica, 9(3), 1977, 195-212.

[22] M.E.B. Fernandes, A structural analysis of Rhizophora, Avicennia, and Laguncularia forests on Maracá Island, Amapá, Brazil, Proc. of the German-Brazilian Workshop, Hamburg, Germany, 2000, 565-572.

[23] R. R. Twilley, and J.W. Day Jr., The productivity and nutrient cycling of mangrove ecosystems, in A. Yáñez-Arancibia, and A. L. Lara-Domínguez (Eds.), Ecosistemas de manglar en América tropical (México: Instituto de Ecología A.C., 1999), $127-152$.

[24] M. Spalding, M.Kainuma, and L. Collins, World atlas of mangroves (London: Earthscan, 2010).

[25] E.C. Ashton, and D.J. Macintosh, Preliminary assessment of the plant diversity and community ecology of the Sematan mangrove forest, Sarawak, Malaysia,Forest Ecology and Management, 166, 2002, 111-129.

[26] J. G. Kairo, J. K. S. Lang'at, F. Dahdouh-Guebas, J. Bosire, and M. Karachi, Structural development and productivity of replanted mangrove plantations in Kenya,Forest Ecology and Management, 255(7), 2008, 2670-2677.

[27] Y.Peng, G.Chen, G.Tian, and X. Yang, Niches of plant population in mangrove reserve of Qi'ao Island, Pearl riverestuary,ActaEcologicaSinica, 29, 2009, 357-361.

[28] S.H.Rashid, R.Böcker, A.B.M.E. Hossain, and S.A. Khan, Undergrowth species diversity of Sundarban mangrove forest (Bangladesh) in relation to salinity, Berichte des Institutes fürLandschafts- und Pflanzenökologie der UniversitätHohenheim, 17, 2007, 41-56. 
[29] B. B. Walters, Ecological effects of small-scale cutting of Philippine mangrove forests,Forest Ecology and Management, 206(1-3), 2005, 331-348.

[30] L. Chen, Q.Zan, M. Li, J. Shen, and W. Liao, Litter dynamics and forest structure of the introduced Sonneratia caseolarismangrove forest in Shenzhen, China,Estuarine, Coastal and Shelf Science, 85(2), 2009, 241-246.

[31] T.E. Fatoyinbo, Growth, dynamics, and distribution of mangrove forests in Mozambique,doctoral diss.,Department of Environmental Sciences, University of Virginia, 2008.

[32] D.R.Satapathy, R.J.Krupadam, L. Pawan Kumar, and S.R. Wate, The application of satellite data for the quantification of mangrove loss and coastal management in the Godavari estuary, east coast of India,Environ Monit Assess, 134, 2007, 453-469.

[33] J.A.C.Pellegrini, M.L.G.Soares, F.O.Chaves, G.C.D. Estrada, andV.F.Cavalcanti, A method for the classification of mangrove forests and sensitivity/vulnerability analysis,Journal of Coastal Research, Special Issue 56, 2009, 443-447.

[34] B.Satyanarayana, A.V.Raman, F.Dehairs, C.Kalavati, and P. Chandramohan, Mangrove floristic and zonation patterns of Coringa, Kakinada bay, east coast of India, Wetlands Ecology and Management, 10, 2002, 25-39.

[35] B. Satyanarayana, A.V. Raman, H.Mohd-Lokman, F.Dehairs, V.S. Sharma, and F. Dahdouh-Guebas, Multivariate methods distinguishing mangrove community structure of Coringa in the Godavari delta, east coast of India,Aquatic Ecosystem Health and Management, 12, 2009, 401-408.

[36] A.I.Robertson, and D.M. Alongi, Tropical mangrove ecosystems (Washington, DC: The American Geophysical Union, 2002).

[37] P.J. Hogarth,Biology of mangroves and seagrasses (2nded.) (New York: Oxford University Press, 2007).

[38] J.G. Watson, Mangrove forests of the Malay peninsula (Malayan Forest Records No.6) (Singapore: Fraser and Neave, 1928).

[39] T.Tomascik, A.J.Mah, A.Nontji, and M.K. Moosa, The ecology of the Indonesia seas: Part two (Republic ofSingapore: PeriplusEditions (HK), 1997).

[40] B.He, T. Lai, H. Fan, W. Wang, and H. Zheng, Comparison of flooding-tolerance in four mangrove species in a diurnal tidal zone in the Beibugulf,Estuarine, Coastal and Shelf Science, 74, 2007, 254-262.

[41] C.D. Field, Rehabilitation of mangrove ecosystems: An overview. Marine Pollution Bulletin, 37(8-12), 1999, $383-392$.

[42] M.S. Iftekhar, Functions and development of reforested mangrove areas: A review,International Journal of Biodiversity Science and Management, 4, 2008, 1-14.

[43] Y.Ye, N.F.Y.Tam, Y.S.Wong, and C.Y. Lu, Growth and physiological responses of two mangrove species (Bruguieragymnorrhiza and Kandeliacandel) to waterlogging,Environmental and Experimental Botany, 49, 2003, 209-221.

[44] Y.Ye, Y.S.Wong, and N.F.Y. Tam, Acclimation of a dominant mangrove plant (Kandeliacandel) to soil texture and its response to canopy shade,Hydrobiologia, 539, 2005, 109-119.

[45] Z. Yihui, W.Wenqing, W.Qiucheng,F.Baizhou, and L. Peng, The growth of Kandeliacandel seedlings in mangrove habitats of theZhangjiang estuary in Fujian, China,ActaEcologicaSinica, 26(6), 2006, 1648-1656.

Table1 Mangrove species and structure in MS2.

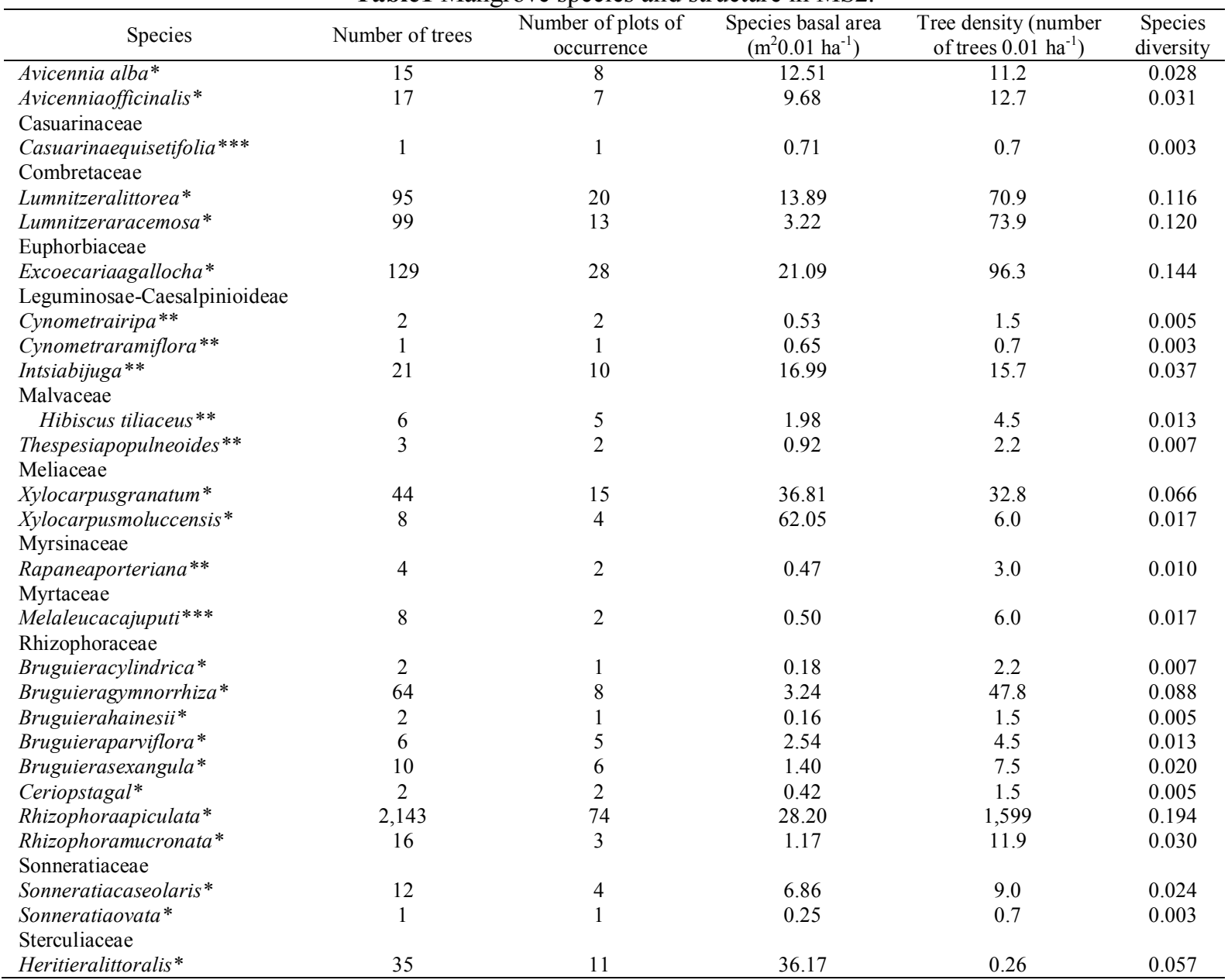

*true mangrove species, ** mangrove associates, ***neither true mangrove species nor mangrove associates 
Table 2 Importance value index of important true mangrove species in the mangrove area.

\begin{tabular}{lcccc}
\hline \multirow{2}{*}{ Species } & \multicolumn{3}{c}{ Relative value (\%) } & \multirow{2}{*}{ Importance Value Index (IVI) } \\
\cline { 2 - 4 } & Density & Dominance & Frequency & 3.40 \\
Avicennia alba & 0.55 & 4.86 & 2.98 & 7.81 \\
Avicenniaofficinalis & 0.62 & 3.76 & 11.91 & 24.80 \\
Excoecariaagallocha & 4.70 & 8.19 & 6.38 & 22.27 \\
Xylocarpusgranatum & 1.60 & 14.29 & 1.70 & 26.08 \\
Xylocarpusmoluccensis & 0.29 & 24.08 & 0.43 & 0.57 \\
Bruguieracylindrica & 0.07 & 0.07 & 3.40 & 6.99 \\
Bruguieragymnorrhiza & 2.33 & 1.26 & 0.43 & 0.56 \\
Bruguierahainesii & 0.07 & 0.06 & 2.13 & 3.33 \\
Bruguieraparviflora & 0.22 & 0.99 & 2.55 & 3.46 \\
Bruguierasexangula & 0.36 & 0.54 & 0.85 & 1.09 \\
Ceriopstagal & 0.07 & 0.16 & 31.49 & 120.48 \\
Rhizophoraapiculata & 78.04 & 10.95 & 1.28 & 2.31 \\
Rhizophoramucronata & 0.58 & 0.45 & 1.70 & 4.80 \\
Sonneratiacaseolaris & 0.44 & 2.66 & 0.43 & 0.56 \\
Sonneratiaovata & 0.04 & 0.10 & & \\
\hline
\end{tabular}

Table 3 Zonesof mangrove species according to landward distances from the river.

Zones

Landward distances from the river $(\mathrm{m}$.

\begin{tabular}{cc}
\hline Zone 1 & $0-90$ \\
Zone 2 & $90-180$ \\
Zone 3 & $180-270$ \\
Zone 4 & $270-360$ \\
Zone 5 & $360-450$ \\
Zone 6 & $450-540$ \\
Zone 7 & $540-630$ \\
Zone 8 & $630-720$ \\
Zone 9 & $>720$ \\
\hline
\end{tabular}

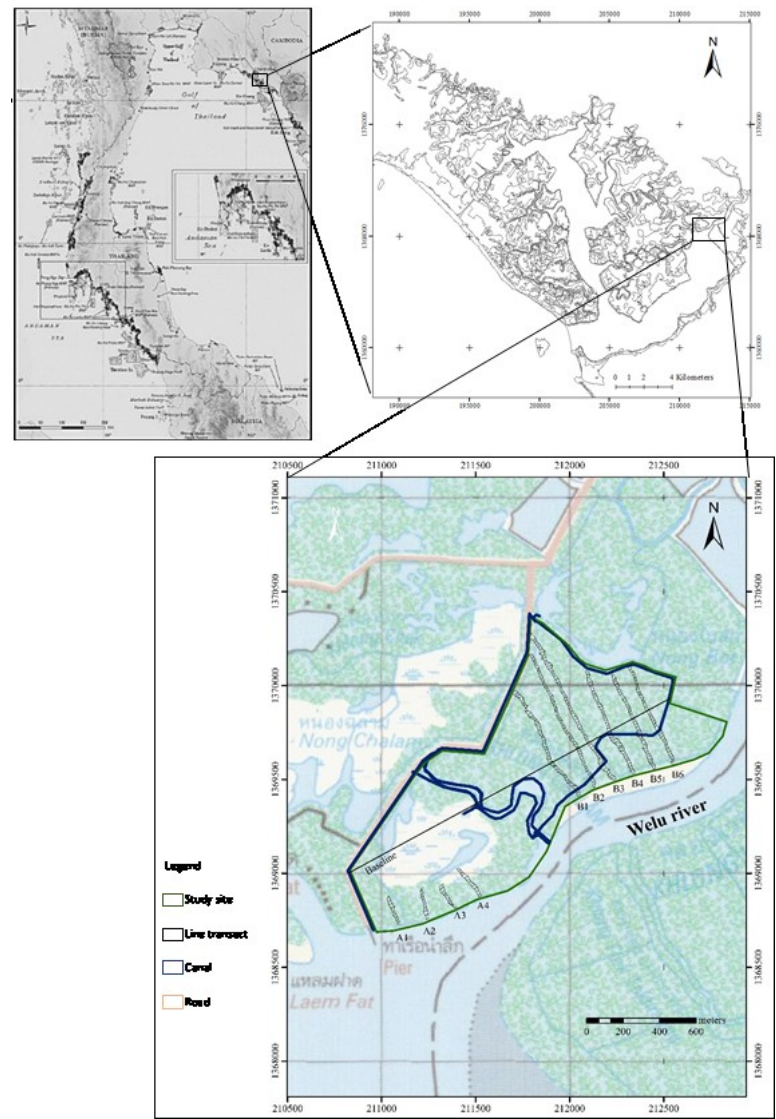

Figure 1 The study site and plots at the Welu estuary. (Modified from Tuck et al., 2012; Office of Mangrove Resources Conservation, n.d.). 


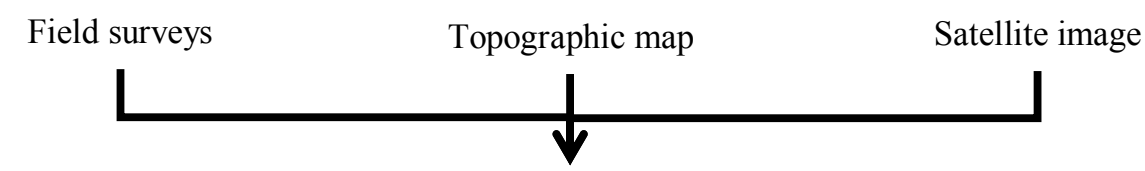

Healthy mangrove forest

Line transects method

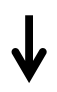

Study plots design

- Species list

Data of mangrove species

- Number of trees - Diameter at breast height

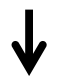

Mangrove structure and composition

Database for mangrove ecology and conservation

Figure 2 Research plan for mangrove ecology and conservation.

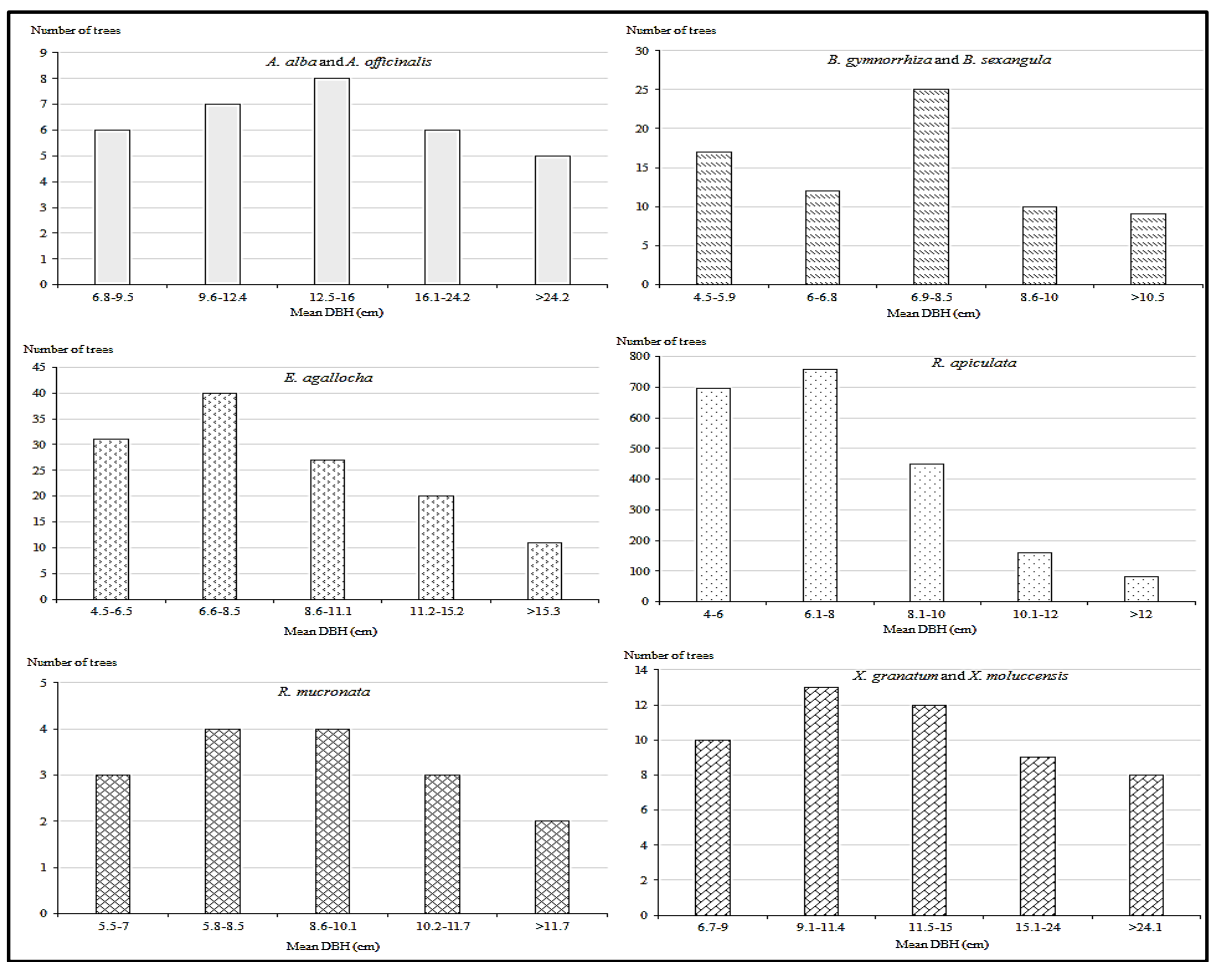

Figure 3Mean DBH of important true mangrove species (except B. cylindrica, B. hainesii, B. parviflora andC. tagal). 


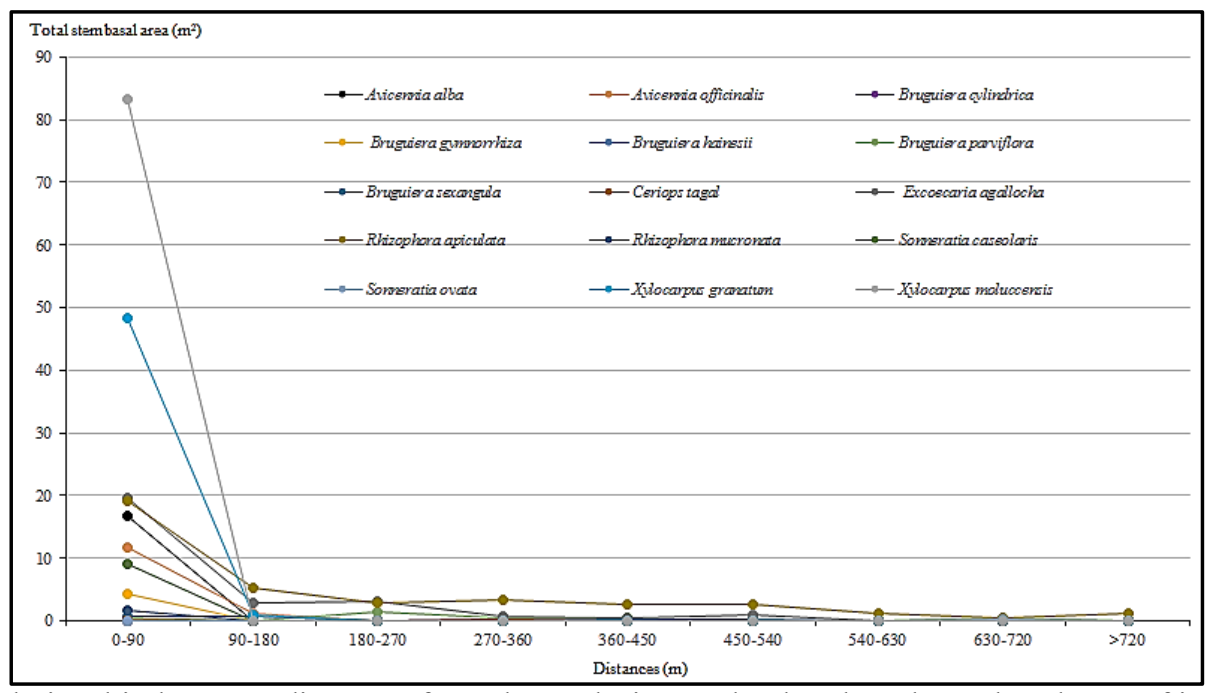

Figure 4 Relationship between distances from the Weluriver to land and totalstem basal area of important true mangrove species.

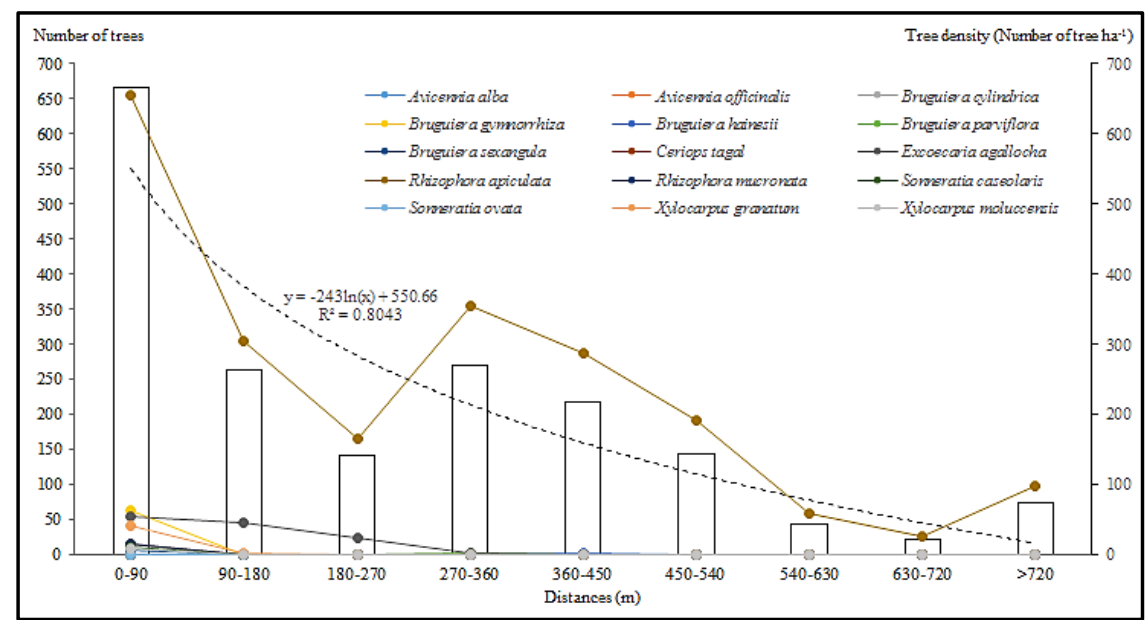

Figure 5 Relationship among distances from the Weluriver to land, number of trees and tree density of important true mangrove species.

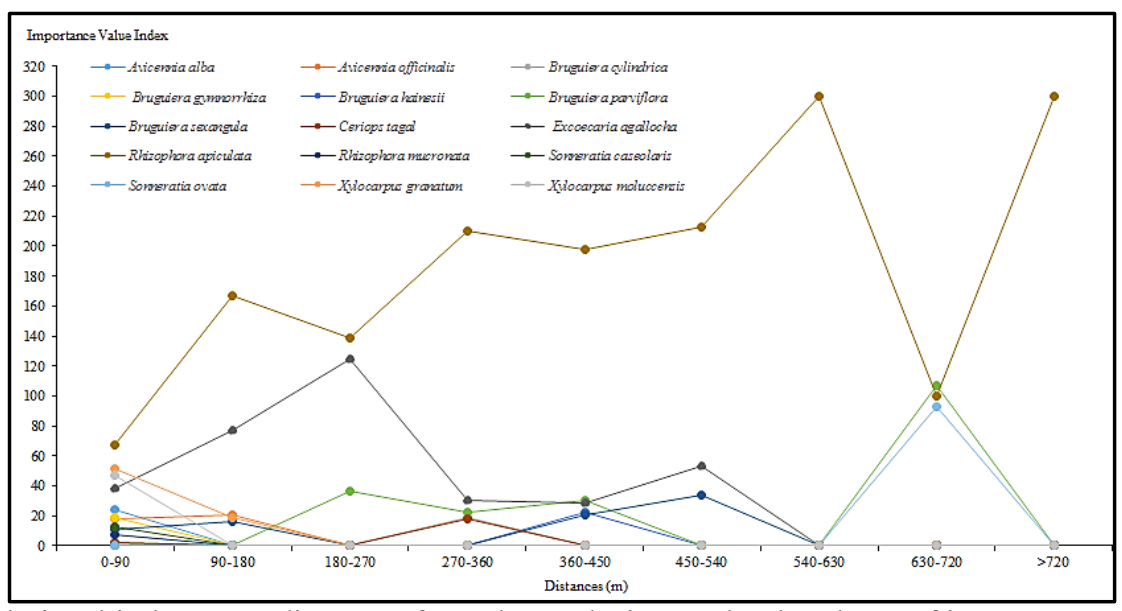

Figure 6 Relationship between distances from the Weluriver to land and IVI of important true mangrove species. 